\title{
Analisis Kesalahan dalam Menyelesaikan Masalah Matematika Kontekstual pada Materi Bangun Ruang Sisi Datar Berdasarkan Newman Error Analysis Ditinjau dari Gender
}

\author{
Khairul Amin ${ }^{1}$, Kamid $^{2}$, Bambang Hariyadi ${ }^{3}$ \\ 1,2,3 Program Studi Magister Pendidikan Matematika, Fakultas Keguruan Ilmu Pendidikan, Universitas Jambi, \\ Jl. Radem Mattaher No. 16-Jambi, Kota Jambi, Indonesia \\ Aminkhairu1562@gmail.com
}

\begin{abstract}
This study aims to analyze student errors in solving contextual math problems based on Newman Error Analysis in terms of gender. This type of research is descriptive qualitative research. In determining the subject of this study using purposive sampling technique. The subjects of this study amounted to 6 people, each consisting of 2 students in the categories of high, medium, and low mathematical abilities. Data collection techniques were carried out by tests and interviews. Based on the results of research on errors made in male and female subjects in solving contextual math problems, male and female students made the same mistakes. In the form of understanding errors, namely not writing down what is known and asked in the questions, transformation errors, namely incorrect in determining the right method in solving problems, process skill errors, namely incorrect calculations in solving problems and previous errors, and errors in writing the final answer, namely not writing down conclusion of the final answer and write down the final but incorrect answer. The factors that cause male and female students' errors in solving contextual math problems also tend to be the same. In the form of not understanding the problem in the problem, not understanding the material, not being careful/careless, and the previous stage error. It's just that the difference between female students is that they are not accustomed to writing down what they know and are asked questions, while male students do not meet these factors.
\end{abstract}

Keywords: Contextual Problems, Newman Error Analysis, Gender

\begin{abstract}
Abstrak
Penelitian ini bertujuan untuk menganalisis kesalahan siswa dalam menyelesaikan masalah matematika kontekstual berdasarkan Newman Error Analysis ditinjau dari gender. Jenis penelitian ini adalah penelitian kualitatif deskriptif. Dalam menentukan subjek penelitian ini menggunakan teknik purposive sampling. Subjek penelitian ini berjumlah 6 orang, masing-masing terdiri atas 2 orang siswa ketegori kemampuan matematika tinggi, sedang dan rendah. Teknik pengumpulan data dilakukan dengan tes dan wawancara. Berdasarkan hasil penelitian mengenai kesalahan yang dilakukan pada subjek laki-laki dan perempuan dalam menyelesaikan masalah matematika kontekstual, siswa lakilaki dan perempuan melakukan kesalahan yang sama. Berupa kesalahan memahami yaitu tidak menuliskan apa yang diketahui dan ditanya pada soal, kesalahan transformasi yaitu salah dalam menentukan metode yang tepat dalam menyelesaikan soal, kesalahan keterampilan proses yaitu salah dalam melakukan perhitungan dalam menyelesaikan soal dan kesalahan sebelumnya, dan kesalahan penulisan jawaban akhir yaitu tidak menuliskan kesimpulan jawaban akhir dan menuliskan jawaban akhir tetapi tidak tepat. Faktor-faktor penyebab kesalahan siswa laki-laki dan perempuan dalam menyelesaikan masalah matematika kontekstual juga cenderung sama. Berupa tidak memahami masalah dalam soal, tidak memahami materi, kurang teliti/ceroboh, dan kesalahan tahap sebelumnya. Hanya saja yang membedakan siswa perempuan memenuhi faktor tidak terbiasa menuliskan apa yang diketahui dan ditanya pada soal sedangkan siswa laki-laki tidak tidak memenuhi faktor tersebut.
\end{abstract}

Kata kunci: Masalah Kontekstual, Newman Error Analysis, Gender

Copyright (c) 2021 Khairul Amin, Kamid, Bambang Hariyadi

$\square$ Corresponding author: Khairul Amin

Email Address: Aminkhairu1562@gmail.com (Jl. Radem Mattaher No. 16-Jambi, Kota Jambi, Indonesia)

Received 14 June 2021, Accepted 15 July 2021, Published 21 July 2021

\section{PENDAHULUAN}

Pendidikan merupakan suatu upaya untuk mewujudkan suasana belajar dan proses pembelajaran yang aktif (Amelia et al. 2020). Setiap siswa dalam pendidikan dituntut untuk bersikap aktif sehingga 
kemampuan dan potensi yang dimiliki dapat berkembang secara maksimal. Salah satu usaha yang dapat dilakukan untuk mengembangkan potensi yang dimiliki siswa yaitu melalui pembelajaran matematika.

Matematika mempunyai peranan sangat penting dalam mencerdaskan peserta didik. Matematika mengembangkan kemampuan berpikir kritis, analitis, dan logis melalui pemecahan masalah. Penyelesaian masalah memerlukan berbagai keterampilan seperti interpretasi informasi, perencanaan dan penyelesain, pengecekan hasil dan alternative strategi (Intaros et al. 2014).

Matematika memiliki peran penting dalam membangun pola pikir logis dan sistematis seseorang sehingga mempelajari mempelajari matematika dapat meningkatkan kemampuan menghadapi masalah, baik dalam permasalahan matematika maupun permasalahan sehari-hari. Salah satu usaha yang dapat dilakukan untuk mencapai sasaran tersebut yaitu dengan mengenalkan permasalahan kontekstual matematika untuk dipecahkan kepada siswa.

Masalah matematika kontekstual adalah masalah matematika yang berkaitan dengan konteks, baik berkaitan langsung dengan objek nyata atau berkaitan langsung dengan objek abstrak seperti fakta, konsep dan prinsip matematika. Konsep matematika muncul dari proses matematisasi yaitu dimulai dari penyelesaian yang berkaitan dengan konteks, siswa secara perlahan mengembangkan pemahaman matematis ke tingkat yang lebih formal (Siswandi et al. 2016).

Pemahaman konsep matematika merupakan aspek yang paling mendasar bagi siswa. Apabila siswa kurang memahami konsep maka siswa hanya sekedar menguasai prosedur penyelesaian tanpa mengerti secara pasti hakikat dari penyelesaian masalah tersebut. Bahkan kurangnya pemahaman konsep matematika dapat mengakibatkan siswa kurang mampu menterjemahkan suatu permasalahan kedalam bahasa matematika sehingga sering terjadi kesalahan pada siswa dalam menyelesaikan soal pemecahan masalah. Apabila siswa diberikan soal aplikasi atau soal-soal yang berbeda dengan soal-soal yang telah dicontohkan oleh guru, maka siswa cenderung membuat kesalahan 'error'. Kesalahan yang dilakukan siswa ada umumnya terletak pada penggunaan rumus, pemahaman atau kemampuan mencerna bahasa matematika, dan kemampuan mengaplikasikan konsep.

Berdasarkan penelitian awal/observasi penulis lakukan di SMPN 7 Muaro Jambi, terlihat hasil ulangan harian salah satu jawaban siswa kelas VIII F dimana siswa banyak melakukan kesalahan berdasarkan prosedur Newman, yaitu Kesalahan Memahami, Kesalahan Transformasi, Kesalahan Keterampilan Proses, dan Kesalahan Penulisan Jawaban Akhir.

Pada Kesalahan Memahami siswa tidak menuliskan apa yang diketahui dan ditanya pada soal, pada kesalahan transformasi siswa salah dalam memilih metode/rumus yang benar dalam menyelesaikan soal sehingga hasil yang ditemukan salah, pada kesalahan keterampilan proses kesalahan inni terjadi karna kesalahan sebelumnya dimana salah menggunakan kaidah atau aturan matematika yang benar, dan terakhir kesalahan penulisan jawaban akhir dimana siswa tidak menuliskan kesimpulan dari penyelesaian soal tersebut, sehingga dianggap melakukan kesalahan. (Lihat Gambar 1) 


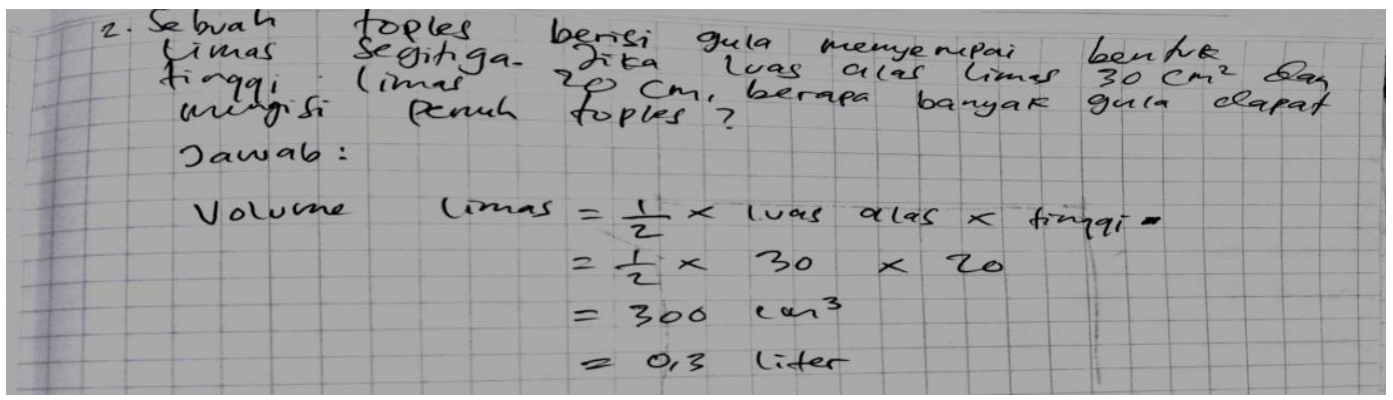

Gambar 1 Hasil Ulangan Siswa

Berdasarkan wawancara dengan guru matematika di SMPN 7 Muaro Jambi, beliau mengungkapkan bahwa masih banyak terdapat kesalahan siswa dalam mengerjakan soal bangun ruang sisi datar. Kesalahan yang sering dialami oleh siswa laki-laki dan perempuan yaitu salah dalam menentukan rumus dalam menyelesaikan soal, sebagian siswa laki-laki dan perempuan pada pokok bahasan tersebut adalah tidak memahami konsep secara benar bagaimana menentukan luas permukaan kubus, balok, prisma, dan limas. Siswa laki-laki juga terkadang mengalami kesalahan pada perhitungan atau komputasi dalam menyelesaiakan soal yang terkait dengan volume limas. Beberapa siswa perempuan juga mengalami kesalahan membedakan diagonal ruang dan bidang diagonal pada kubus dan balok, dan salah dalam menuliskan kesimpulan jawaban akhir. Siswa laki-laki dan perempuan masih banyak terdapat kesalahankesalahan yang dilakukan saat diminta menyelesaikan soal yang berkaitan dengan pemecahan masalah.

Untuk mengurangi kesalahan dalam matematika, guru perlu mengenal berbagai kesalahan yang dilakukan siswa dalam menyelesaikan soal matematika. Menurut Rahardjo \& Waluyati (2011) kesalahankesalahan yang dialami siswa dalam mengerjakan masalah matematika secara mekanik meliputi kesalahan memahami soal, kesalahan membuat model matematika dan kesalahan menginterpretasikan jawaban kalimat matematika. Salah satu cara yang digunakan untuk mengetahui kesalahan belajar yang dialami siswa yaitu dengan menganalisis kesalahan hasil belajar siswa. Dengan menganalisis kesalahan hasil belajar siswa, diharapkan guru dapat mengetahui penyebab siswa mengalami kesalahan siswa dalam menyelesaikan soal cerita.

Seorang guru tidak hanya dituntut untuk memahami dan mengkaji lebih dalam mengenai kesalahan siswa dalam pemecahan masalah matematika, akan tetapi seorang guru hendaknya harus mengetahui faktorfaktor yang mempengaruhi pembelajaran matematika. Menurut Amir (2013) banyak faktor yang harus diperhatikan dalam mempelajari matematika, antara lain yaitu kemauan, kemampuan, dan kecerdasan tertentu, kesiapan guru, kesiapan siswa, kurikulum, dan metode penyajiannya, faktor yang tak kalah pentingnya adalah gender.

Gender merupakan sebagai suatu konsep yang digunakan untuk mengindetifikasi perbedaan laki-laki dan perempuan dilihat dari segi pengaruh sosial budaya. Perbedaan gender tentu menyebabkan perbedaan fisiologi dan mempengaruhi perbedaan psikologi tak terkecuali dalam belajar. Sehingga siswa laki-laki dan perempuan tentu memiliki banyak perbedaan dalam mempelajari matematika. Oleh karena itu aspek gender perlu menjadi perhatian khusus dalam pembelajaran matematika (Latief et al. 2019). 
Adanya pendemi Covid-19 seorang guru harus menemukan cara yang efektif dan efisien untuk memaksimalkan pembelajaran. Menurut Wiratomo \& Mulyatna (2020) seorang guru harus mengupayakan secara maksimal menemukan cara atau metode pembelajaran dan pilihan media yang dinilai efektif dan efesien, mulai dari Whatsapp, google classroom, google meet, zoom dan lain sebagainya.

Pembelajaran daring selama pendemi menurunkan minat dan hasil belajar siswa. Hal ini sejalan dengan penelitian yang dilakukan oleh Yazid \& Ernawati (2020), hasil penelitiannya menunjukkan bahwa sebagian besar belum mencapai ketuntasan belajar sebesar 55\%. Oleh karena itu dapat disimpulkan berdasarkan persentase tertinggi sebesar 15\% berada pada rentang 60-100 menunjukkan bahwa hasil belajar siswa Kelas V MI NW Pancor Kopong tergolong atau berada dalam kategori sedang dan rendah. Sedangkan penelitian yang dilakukan oleh Abdullah et al. (2020), hasil penelitian menunjukkan bahwa hasil belajar matematika siswa melalui pembelajaran daring pada materi bangun ruang sisi datar masih termasuk dalam kategori kurang dan pembelajaran yang dilakukan dengan menggunakan facebook messenger belum memberikan hasil yang maksimal.

Berdasarkan penelitian yang dilakukan Savitri \& Yuliani (2020). Hasil penelitian menunjukkan terdapat perbedaan jenis kesalahan yang dilakukan oleh laki-laki dan perempuan, yakni siswa dengan gender perempuan melakukan kesalahan pada tahap comprehension dan process skil lebih sedikit dibandingkan siswa dengan gender laki-laki. Sedangkan, dalam tahapan transformation serta encoding letak kesalahan yang dilakukan siswa dengan gender laki-laki lebih sedikit dibandingkan siswa perempuan. Sedangkan penelitian yang dilakukan Mulyani \& Muhtadi (2019). Hasil penelitian menunjukkan terdapat perbedaan jenis kesalahan yang dilakukan oleh subjek laki-laki dan perempuan dalam menyelesaikan soal, meliputi: (1) kesalahan membaca, (2) kesalahan pemahaman, (3) kesalahan transformasi, (4) kesalahan keterampilan proses, dan (5) kesalahan penulisan jawaban. Kesalahan paling banyak dilakukan siswa yaitu kesalahan pemahaman, kesalahan transformasi, dan penulisan jawaban.

Metode analisis Newman Error Analisis (NEA) diperkenalkan oleh Anne Newman pada tahun 1977. Dalam metode ini, Newman menyarankan lima kegiatan yang dapat membantu menemukan kesalahan yang terjadi pada pekerjaan siswa ketekika menyelesaikan masalah matematika. Menurut Newman mengemukakan bahawa setiap siswa yang ingin menyelesaikan masalah matematika, mereka harus bekerja melalui lima langkah berikut, yaitu membaca (reading), memahami (comprehension), mentransformasi (transformation), melakukan proses penyelesaian (process skill), dan melaukan penulisan jawaban akhir (according) (Siswandi et al. 2016).

\section{METODE}

Penelitian ini dilaksanakan di SMPN 7 Muaro Jambi pada semester genap tahun ajaran 2020/2021. Penelitian ini termasuk penelitian kualitatif deskriptif. Penelitian kualitatif ini digunakan untuk mendapatkan data yang mendalam dengan tujuan mengetahui kesalahan siswa dalam menyelesaikan masalah kontektual matematika pada materi abngun ruang sisi datar. Penelitian kualitatif adalah penelitian yang bermaksud untuk memahami fenomena tentang apa yang dialami oleh subjek penelitian misalnya 
perilaku, persepsi, motivasi, tindakan, dll., secara holistik, dan dengan cara deskripsi dalam bentuk katakata dan bahasa, pada suatu konteks khusus yang alamiah dan dengan memanfaatkan berbagai metode alamiah (Moleong, 2005). Teknik pengambilan subjek dilakukan dengan purposive sampling berdasarkan hasil tes soal uraian. Dari hasil pemilihan subjek, ditentukan sebanyak 6 subjek yaitu terdiri dari 3 subjek laki-laki dan 3 subjek perempuan dengan ketentuan kemampuan dalam kategori tinggi 2 subjek, kemampuan dalam kategori sedang 2 subjek dan kemampuan dalam kategori rendah 2 subjek dengan tiap kategori terdiri dari laki-laki dan perempuan.

Teknik analisis data dalam penelitian ini mengacu pada Miles dan Huberman yang meliputi reduksi data, penyajian data dan penarikan kesimpulan (Sugiyono, 2017). Teknik pengumpulan data dalam penelitian ini menggunakan tes dan wawancara. Teknik tes dalam penelitian ini tes diberikan untuk memperoleh data hasil pekerjaan siswa dalam menyelesaikan soal materi bangun ruang sisi datar. Dari hasil pekerjaan yang diperoleh dapat diperoleh letak kesalahan yang dilakukan oleh siswa. Sedangkan teknik wawancara dalam penelitian ini digunakan sebagai teknik pendukung disamping tes untuk memperoleh gambaran dalam mengenalisis data. Wawancara bertujuan untuk memperoleh informasi tentang jenis-jenis kesalahan siswa laki-laki dan siswa perempuan dalam menyelesaikan masalah kontekstual matematika padad materi bangun ruang sisi datar berdasarkan Nerman Error Analysis. Secara lengkap prosedur pengumpulan data dalam penelitian ini dijelaskan dengan mengunakan diagram pada Gambar 2.

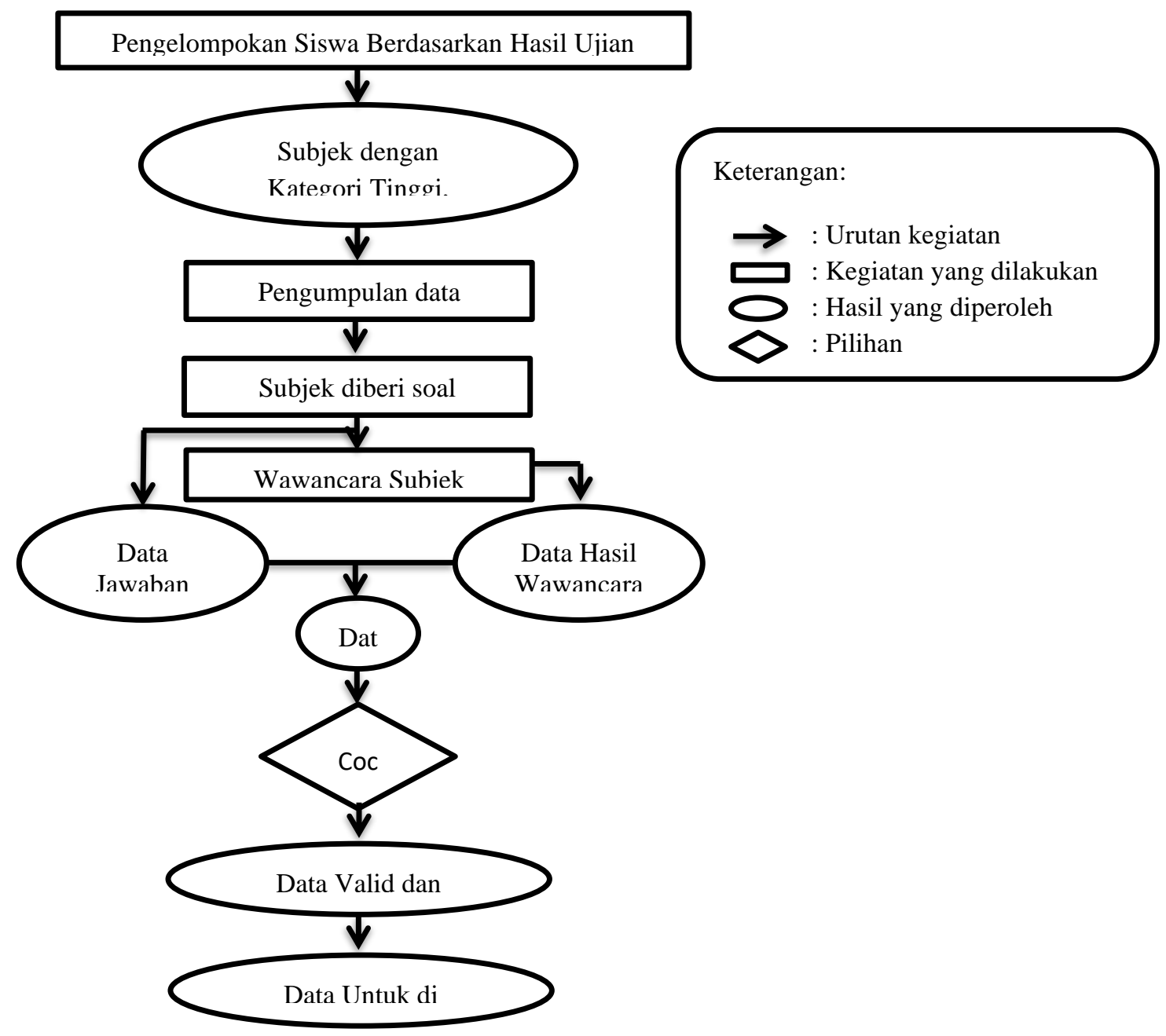

Gambar 2 Diagram Prosedur Pengumpulan Data 


\section{HASIL DAN DISKUSI}

Dalam penelitian ini, soal tes dalam bentuk uraian digunakan untuk mengetahui jenis kesalahan yang dilakukan siswa. Sedangkan wawancara yang digunakan untuk mengetahui penyebab siswa melakukan kesalaan tersebut. Setelah melakukan analisis dan mengelompokkan kesalahan yang dilakukan siswa, peneliti menyajikan dalam bentuk tabel untuk setiap nomor soal. Berikut disajikan tabel jenis kesalahan yang dilakukan siswa laki-laki dan siswa perempuan.

Tabel 1 Jumlah Kesalahan Siswa Laki-Laki

\begin{tabular}{|c|c|c|c|c|c|c|}
\hline \multirow[t]{2}{*}{ Subjek } & \multirow{2}{*}{$\begin{array}{c}\text { Nomor } \\
\text { Soal }\end{array}$} & \multicolumn{5}{|c|}{ Jenis Kesalahan } \\
\hline & & $\mathbf{R}$ & $\mathrm{C}$ & $\mathbf{T}$ & $\mathbf{P}$ & $\mathbf{E}$ \\
\hline \multirow[t]{5}{*}{ SL1 } & 1 & - & $\sqrt{ }$ & $\sqrt{ }$ & $\sqrt{ }$ & $\sqrt{ }$ \\
\hline & 2 & - & - & - & - & - \\
\hline & 3 & - & - & $\sqrt{ }$ & $\sqrt{ }$ & $\sqrt{ }$ \\
\hline & 4 & - & - & - & - & - \\
\hline & 5 & - & - & - & - & - \\
\hline \multirow[t]{5}{*}{ SL2 } & 1 & - & - & $\sqrt{ }$ & $\sqrt{ }$ & $\sqrt{ }$ \\
\hline & 2 & - & - & - & - & $\sqrt{ }$ \\
\hline & 3 & - & $\sqrt{ }$ & $\sqrt{ }$ & $\sqrt{ }$ & $\sqrt{ }$ \\
\hline & 4 & - & - & - & - & $\sqrt{ }$ \\
\hline & 5 & - & - & - & - & $\sqrt{ }$ \\
\hline \multirow[t]{5}{*}{ SL3 } & 1 & - & $\sqrt{ }$ & $\sqrt{ }$ & $\sqrt{ }$ & $\sqrt{ }$ \\
\hline & 2 & - & $\sqrt{ }$ & - & $\sqrt{ }$ & $\sqrt{ }$ \\
\hline & 3 & - & $\sqrt{ }$ & - & $\sqrt{ }$ & $\sqrt{ }$ \\
\hline & 4 & - & $\sqrt{ }$ & - & $\sqrt{ }$ & $\sqrt{ }$ \\
\hline & 5 & - & $\sqrt{ }$ & - & $\sqrt{ }$ & $\sqrt{ }$ \\
\hline \multicolumn{2}{|c|}{ Jumlah } & - & 7 & 5 & 9 & 12 \\
\hline
\end{tabular}

Tabel 2 Jumlah Kesalahan Siswa Perempuan

\begin{tabular}{|c|c|c|c|c|c|c|}
\hline \multirow[t]{2}{*}{ Subjek } & \multirow{2}{*}{$\begin{array}{c}\text { Nomor } \\
\text { Soal }\end{array}$} & \multicolumn{5}{|c|}{ Jenis Kesalahan } \\
\hline & & $\mathbf{R}$ & $\mathbf{C}$ & $\mathbf{T}$ & $\mathbf{P}$ & $\mathbf{E}$ \\
\hline \multirow[t]{5}{*}{ SP1 } & 1 & - & - & $\sqrt{ }$ & $\sqrt{ }$ & $\sqrt{ }$ \\
\hline & 2 & - & - & - & - & $\sqrt{ }$ \\
\hline & 3 & - & - & $\sqrt{ }$ & $\sqrt{ }$ & $\sqrt{ }$ \\
\hline & 4 & - & $\sqrt{ }$ & - & - & $\sqrt{ }$ \\
\hline & 5 & - & - & - & - & $\sqrt{ }$ \\
\hline \multirow[t]{5}{*}{ SP2 } & 1 & - & - & $\sqrt{ }$ & $\sqrt{ }$ & $\sqrt{ }$ \\
\hline & 2 & - & - & $\sqrt{ }$ & - & $\sqrt{ }$ \\
\hline & 3 & - & - & $\sqrt{ }$ & $\sqrt{ }$ & $\sqrt{ }$ \\
\hline & 4 & - & $\sqrt{ }$ & - & - & $\sqrt{ }$ \\
\hline & 5 & - & - & $\sqrt{ }$ & $\sqrt{ }$ & $\sqrt{ }$ \\
\hline \multirow[t]{5}{*}{ SP3 } & 1 & - & - & $\sqrt{ }$ & $\sqrt{ }$ & $\sqrt{ }$ \\
\hline & 2 & - & - & $\sqrt{ }$ & $\sqrt{ }$ & $\sqrt{ }$ \\
\hline & 3 & - & $\sqrt{ }$ & $\sqrt{ }$ & $\sqrt{ }$ & $\sqrt{ }$ \\
\hline & 4 & - & $\sqrt{ }$ & $\sqrt{ }$ & - & $\sqrt{ }$ \\
\hline & 5 & - & - & - & - & $\sqrt{ }$ \\
\hline \multicolumn{2}{|c|}{ Jumlah } & - & 4 & 10 & 8 & 15 \\
\hline
\end{tabular}

Untuk menganalisis kesalahan yang dilakukan oleh siswa dalam menyelesaikan soal, dilakukan analisis yang lebih mendalam terhadap siswa pada masiang-masing soal pada jenis-jenis kesalahan yang 
dilakukan siswa berdasarakan Newman Error Analysis. Identifikasi siswa yang diperoleh berdasarkan kesalahan siswa mengerjakan tes, sebagai berikut:

\section{Kesalahan Membaca (Reading Error)}

Pada Kesalahan Membaca baik siswa laki-laki maupun siswa perempuan tidak melakukan kesalahan membaca karena subjek dapat membaca soal, kata-kata penting dan informasi utama dengan benar tanpa adanya kesalahan pada pelafalan sehingga dapat disimpulkan bahwa subjek tidak memenuhi indikator kesalahan membaca. Hal ini juga sama dengan penelitian yang dilakukan oleh (Satoto et al. 2012) bahwa dari 6 subjek penelitian, semua subjek dapat melewati langkah membaca tanpa adanya kesalahan. Hal ini dikarenakan masalah kontekstual matematika yang digunakan berbentuk soal cerita yang menggunakan bahasa Indonesia. Kata-kata yang digunakan di dalam soal tidak menggunakan istilah asing yang menyulitkan pengucapan siswa. Serta permasalahan yang ada pada soal juga merupakan permasalahan yang dekat dengan siswa. Sehingga kemungkinan siswa melakukan kesalahan membaca sangat kecil. Namun walaupun demikian masih ada kemungkinan siswa tidak dapat memaknai kalimat yang mereka baca secara tepat.

\section{Kesalahan Memahami (Comprehension Error)}

Berikut potongan gambar dari hasil lembar soal yang dikerjakan oleh siswa untuk soal nomor 1 terkait kesalahan memahami.

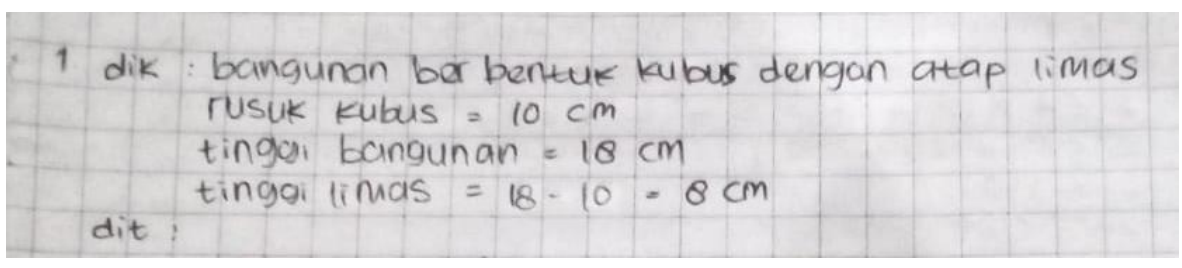

Gambar 3. Kesalahan Memahami (Comprehension Error)

Berdasarkan hasil wawancara terlihat bahwa siswa tidak menuliskan apa yang ditanyakan pada lembar jawaban. Sehingga siswa dianggap melakukan kesalahan memahami karena memenuhi indikator kesalahan memahami pada prosedur Newman Error Analysis.

Pada kesalahan memahami (Comprehension Error) yang dilakukan oleh siswa. Kesalahan memahami menjadi kesalahan pertama yang dilakukan oleh siswa laki-laki dan perempuan. Siswa laki-laki dengan kemampuan awal dalam kategori tinggi dan sedang hanya melakukan satu kesalahan memahami. Sedangkan, siswa laki-laki dengan kemampuan awal dalam kategori rendah melakukan kesalahan memahami pada kelima soal dikarenakan tidak terbiasa menyelesaikan soal yang berbentuk soal cerita, namun siswa tersebut tetap bisa melanjutkan penyelesaian soal pada tahap selanjutnya. Sedikit berbeda dari siswa laki-laki, siswa perempuan dengan kemampuan awal dalam kategori tinggi dan sedang juga melakukan satu kesalahan memahami, sedangkan siswa laki-laki dengan kemampuan awal dalam kategori rendah melakukan lima kesalahan memahami dari lima soal yang diberikan dan siswa perempuan melakukan dua kesalahan. Ini mengindikasikan bahwa siwa dengan kemampuan awal dalam kategori tinggi dan sedang mampu memahami permasalahan yang terdapat pada soal. Sedangkan pada siswa dengan 
kemampuan awal dalam kategori rendah baik siswa laki-laki dan siswa perempuan umumnya melakukan kesalahan memahami dikarenakan kurang memahami maksud atau makna soal. Sehingga kesalahan tersebut mempengaruhi kesalahan-kesalahan pada tahap selanjutnya.

Ini mengindikasikan bahwa siwa dengan kemampuan awal dalam kategori tinggi dan sedang mampu memahami permasalahan yang terdapat pada soal. Hal ini sejalan dengan hasil penelitian (Faizati et al. 2011) bahwa pada siswa dengan kategori kemampuan tinggi dan sedang, kesalahan pada tahap comprehension ini tidak berpengaruh terhadap tahap transformation dan process skill. Namun, kesalahan ini menyebabkan kesalahan dalam menuliskan jawaban akhir (encoding).

Sedangkan pada siswa dengan kemampuan awal matematis rendah baik siswa laki-laki dan siswa perempuan umumnya melakukan kesalahan memahami dikarenakan kurang memahami maksud atau makna soal. Sehingga kesalahan tersebut mempengaruhi kesalahan-kesalahan pada tahap selanjutnya. Hal ini sejalan dengan hasil penelitian (Faizati et al. 2011) bahwa pada siswa dengan kategori kemampuan rendah, kesalahan memahami ini berpengaruh terhadap 3 tahap berikutnya. Kesalahan yang dilakukan oleh siswa dengan kategori rendah ini dikarenakan siswa kurang memahami maksud atau makna soal.

\section{Kesalahan Transformasi (Transformation Error)}

Berikut potongan gambar dari hasil lembar soal yang dikerjakan oleh siswa untuk soal nomor 1 terkait kesalahan transformasi.

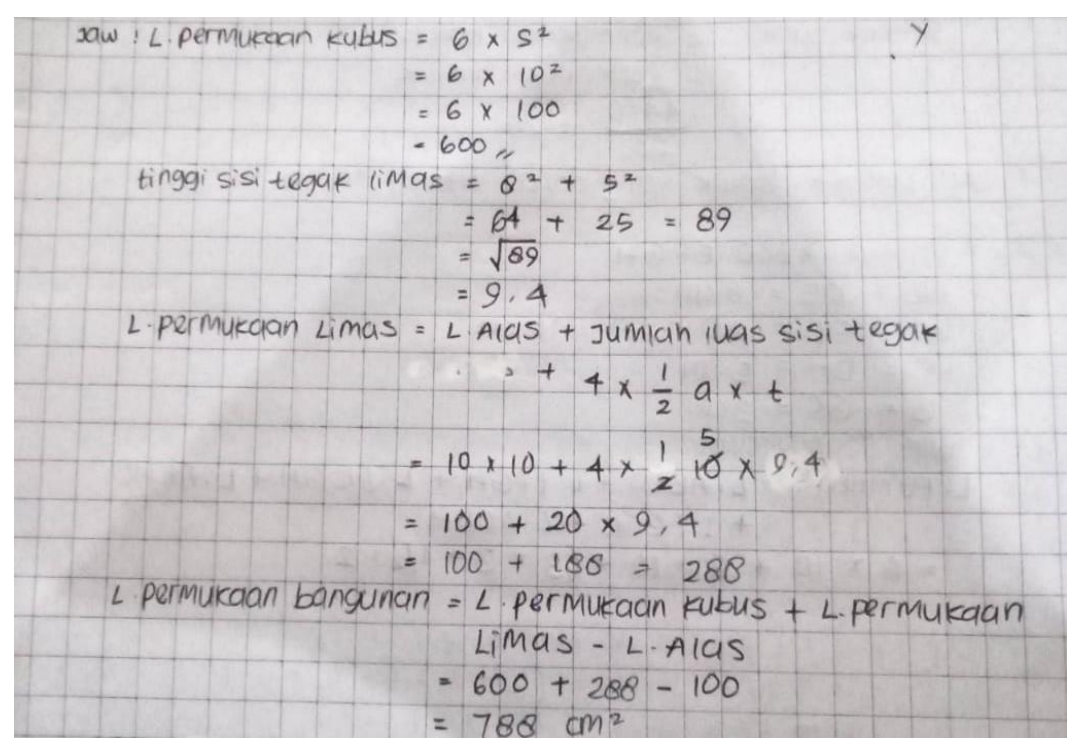

Gambar 4. Kesalahan Transformasi (Transformation Error)

Pada Gambar 4 terlihat bahwa siswa sudah hampir benar melakukan langkah-langkah dalam melakukan penyelesaian soal tersebut tapi siswa salah dalam menuliskan metode atau rumus yang digunakan. Rumus pada langkah pertama seharusnya adalah rumus luas permukaan kubus tanpa tutup yaitu $5 \times s^{2}$, langkah selanjutnya subjek mencari luas permukaan limas tanpa alas yang mana rumus yang digunakan adalah $4\left(\frac{1}{2} \times a \times t\right)$ dan langkah terakhir adalah menjumlahkan luas permukaan kubus tanpa tutup dan luas permukaan limas tanpa alas. Akan tetapi siswa salah dalam menentukan metode atau rumus yang digunakan 
dalam menyelesaikan permasalahan pada soal nomor 1. Sehingga siswa memenuhi indikator kesalahan transformasi karena subjek subjek menuliskan metode/rumus yang tidak tepat dan subjek salah dalam menentukan rangkaian operasi yang tepat.

Pada Kesalahan Memahami yang dilakukan oleh siswa laki-laki maupun siswa perempuan, dimana subjek tidak dapat menentukan metode/operasi maupun rangkaian operasi yang tepat untuk menyelesaikan permasalahan pada soal. Siswa perempuan melakukan kesalahan terbanyak pada kesalahan transformasi, pada kategori transformasi ini masih banyak siswa yang salah dalam mentransformasikan informasi yang mereka ketahui kedalam metode dan kalimat matematika yang benar sehingga kesulitan dalam pengolahan matematis itu sendiri. Sejalan dengan peneilitian tang dilakukan oleh (Rahmawati \& Permata, 2018) tidak mampu membuat model matematika serta tidak mampu menentukan rumus serta langkah penyelesaian yang tepat untuk menyelesaikan masalah pada soal. Hal ini juga sejalan dengan penelitian yang dilakukan oleh (Magfirah et al. 2019) kesalahan transformasi disebabkan karena siswa tidak dapat mengingat rumus, penggunaan rumus tidak tepat, perancangan rumus yang tidak sesuai, penggunan rumus yang terbalik, penafsiran terhadap soal yang tidak tepat, tidak terbiasa mengerjakan soal cerita materi luas permukaan bangun ruang sisi datar, penguasaan materi yang kurang dikarenakan kurangnya mempelajari kembali materi yang telah diperoleh.

\section{Kesalahan Kemampuan Proses (Process Skill Error)}

Berdasarkan jawaban yang ditulis oleh siswa untuk menyelesaikan soal nomor 1 yang dapat dilihat pada Gambar 4, terlihat bahwa melakukan kesalahan dalam perhitungan atau komputasi dalam menyelesaikan soal. Dimana untuk menyelesaikan perhitungan dengan pendekatan yang dipilih oleh siswa, seharusnya siswa menulis langkah dan hasil dari perhitungan luas permukaan limas tanpa alas dan luas permukaan kubus tanpa tutup kemudian menjumlahkan hasilnya. Bukan dengan perhitungan yang ditulis oleh siswa yang tanpa diketahui alur dan proses perhitungannya. Sehingga siswa memenuhi indikator kesalahan Keterampilan Proses karena subjek tidak menuliskan tahapan perhitungan.

Kesalahan kemampuan proses dalam penelitian ini kebanyakan disebabkan karena kesalahan pada tahap sebelumnya, baik pada tahap memahami maupun tahap transformasi. Hal ini sejalan dengan penelitian oleh (Rahmawati \& Permata, 2018) bahwa kesalahan disebabkan oleh kesalahan sebelumnya, pada kesalahan keterampilan proses, masih banyak ditemukan siswa yang melakukan kesalahan yaitu berupa kesalahan konsep, kesalahan komputasi dan kesalahan dalam menentukan operasi hitung serta langkahlangkah penyelesaiannya. Sebenarnya tidak sedikit siswa yang mampu menentukan operasi hitung namun tidak mengetahui langkah-langkah yang akan digunakan untuk menyelesaikan masalah dengan tepat, sehingga banyak siswa yang tidak melanjutkan prosedur penyelesaian hingga selesai. Hal ini sejalan juga dengan pendapat (Jha, 2012) bahwa kesalahan keterampilan proses yaitu siswa mampu mengidentifikasi operasi yang sesuai, atau serangkaian operasi, tetapi tidak tahu langkah-langkah yang diperlukan untuk melaksanakan operasi ini dengan sempurna. 


\section{Kesalahan Penulisan Jawaban Akhir (Encoding Error).}

Berikut potongan gambar dari hasil lembar soal yang dikerjakan oleh siswa untuk soal nomor 1 terkait kesalahan penulisan jawaban akhir.

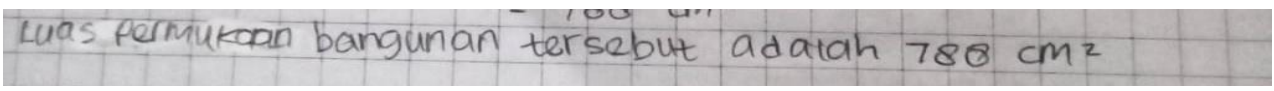

Gambar 5. Kesalahan Penulisan Jawaban Akhir (Encoding Error).

Pada Gambar 5 terlihat bahwa siswa melakukan kesalahan dalam menuliskan jawaban akhir. Sehingga, siswa memenuhi indikator kesalahan penulisan jawaban akhir karena subjek salah dalam menuliskan jawaban akhir. Hal ini disebabkan karena siswa salah dalam menentukan rangkaian operasi matematika yang tepat. Pada kesalahan penulisan jawaban akhir yang dilakukan oleh siswa yaitu : siswa tidak mampu menemukan hasil akhir dari soal dengan benar dan siswa tidak mampu menunjukkan jawaban akhir dengan benar serta tidak dapat menuliskan jawaban akhir sesuai dengan kesimpulan. (Santoso et al. 2017) menjelaskan kesalahan jawaban akhir sangat disayangkan, karena siswa telah berhasil mencapai tahap pengolahan data tetapi gagal untuk menuliskan solusi akhir. Kesalahan ini terjadi karena kesalahan dan kurang memahami siswa tentang isu-isu yang bersangkutan.

Berdasarkan pemaparan diatas, peneliti akan menganalisis kembali faktor-faktor yang menyebabkan siswa laki-laki dan perempuan dalam menyelesaikan masalah kontesktual matematika pada materi Bangun Ruang Sisi Datar. Berikut fator-faktor penyebab kesalahan siswa laki-laki dan perempuan dalam menyelasikan masalah kontesktual matematika pada materi bangun ruang sisi datar, yaitu: kurang teliti/ceroboh, kurangnya penguasaan materi, tidak terbaiasa menjawab soal dalam bentuk cerita, kesalahan sebelumnya dan tidak dapat memaknai masalah dalam soal.

\section{KESIMPULAN}

Berdasarkan hasil penelitian dan pembahasan, maka diperoleh jenis-jenis kesalahan siswa laki-laki dan perempuan kelas VIII F dalam menyelesaikan masalah kontekstual matematika berdasarkan Newman Error Analysis. Apabila dilihat dari banyaknya jenis kesalahan siswa laki-laki dan perempuan dapat ditarik suatu kesimpulan bahwa siswa laki-laki dan perempuan melakukan kesalahan yang cenderung sama. Berupa kesalahan memahami (Comprehension Error), kesalahan transformasi (transformation error), kesalahan kemampuan proses (process skill error), dan kesalahan penulisan jawaban akhir (encoding error).

Faktor-faktor penyebab kesalahan siswa laki-laki dan perempuan dalam menyelesaikan masalah kontekstual matematika juga cenderung sama. Berupa tidak memahami masalah dalam soal, tidak memahami materi, kurang teliti/ceroboh, dan kesalahan tahap sebelumnya. Hanya saja yang membedakan siswa perempuan memenuhi faktor tidak terbiasa menuliskan apa yang diketahui dan ditanya pada soal sedangkan siswa laki-laki tidak memenuhi faktor.

\section{UCAPAN TERIMA KASIH}

Ucapan terima kasih disampaikan kepada Universitas Jambi selaku instansi tempat peneliti 
Analisis Kesalahan dalam Menyelesaikan Masalah Matematika Kontekstual pada Materi Bangun Ruang Sisi Datar Berdasarkan Newman Error Analysis Ditinjau dari Gender, Khairul Amin, Kamid, Bambang Hariyadi

menempuh pendidikan, SMPN 7 Muaro Jambi yang sudah memfasilitasi penelitian dan kepada segenap pihak yang telah turut serta membantu terlaksananya penelitian.

\section{REFERENSI}

Abdullah, A. W., Achmad, N., \& Fahrudin, N. C. (2020). Deskripsi Hasil Belajar Matematika Siswa Melalui Pembelajaran Daring Pada Pokok Bahasan Bangun Ruang Sisi Datar. Euler: Jurnal Ilmiah Matematika, Sains Dan Teknologi, 8(2), 36-41. https://doi.org/10.34312/euler.v8i2.10324

Amelia, M., Sariningsih, R., \& Hidayat, W. (2020). Analisis Persepsi Kesalahan Siswa Smp Pada Soal Materi Statistika Ditinjau dari Perbedaan Gender. Jurnal Pembelajaran Matematika Inovatif, 3(5), 475-484. https://doi.org/10.22460/jpmi.v3i5.475-484

Amir, Z. M. (2013). Perspektif Gender Dalam Pembelajaran Matematika. Marwah: Jurnal Perempuan, Agama Dan Jender, 12(1), 15. https://doi.org/10.24014/marwah.v12i1.511

Atiqoh, K. S. N. (2019). Analisis Kesalahan Siswa Dalam Menyelesaikan Soal Pemecahan Masalah Pada Materi Pokok Bangun Ruang Sisi Datar. ALGORITMA Journal of Mathematics Education, 1(1), 63 73. https://doi.org/10.15408/ajme.v1i1.11687

Faizati, P. S. D., Nusantara, T., \& Qohar, A. (2011). Analisis Kesalahan dan Perilaku yang dilakukan Siswa Kelas VII-C MTs Darul Huda Pasuruan Dalam Mata Pelajaran Matematika. Universitas Negeri Malang, 312-473.

Intaros, P., Inprasitha, M., \& Srisawadi, N. (2014). Students' Problem Solving Strategies in Problem Solving-mathematics Classroom. Procedia - Social and Behavioral Sciences, 116(June 2015), 4119 4123. https://doi.org/10.1016/j.sbspro.2014.01.901

Jha, S. K. (2012). Mathematics performance of primary school students in Assam (India): An analysis using Newman Procedure. International Journal of Computer Applications in in Engineering Sciences, II(I), $17-21$.

Latief, A., Maryam, S., \& Yusuf, M. (2019). Kesetaraan Gender dalam Budaya Sibaliparri Masyarakat Mandar. Pepatudzu: Media Pendidikan Dan Sosial Kemasyarakatan, 15(2), 160. https://doi.org/10.35329/fkip.v15i2.474

Magfirah, M., Maidiyah, E., \& Suryawati, S. (2019). Analisis Kesalahan Siswa Dalam Menyelesaikan Soal Cerita Matematika Berdasarkan Prosedur Newman. Lentera Sriwijaya: Jurnal Ilmiah Pendidikan Matematika, 1(2), 1-12. https://doi.org/10.36706/jls.v1i2.9707

Moleong, L. J. (2005). Metodologi Penelitian Kualitatif. Remaja Rosdakarya.

Mulyani, M., \& Muhtadi, D. (2019). Analisis Kesalahan Siswa Dalam Menyelesaikan Soal Trigonometri Tipe Higher Order Thinking Skill Ditinjau Dari Gender. Jurnal Penelitian Dan Pembelajaran Matematika, 12(1), 1-16. https://doi.org/10.30870/jppm.v12i1.4851

Rahardjo, M., \& Waluyati, A. (2011). Pembelajaran Soal Cerita pada Operasi Hitung Campuran di SD. Modul Matematika SD Program, viii +85 .

Rahmawati, D., \& Permata, L. D. (2018). Analisis Kesalahan Siswa Dalam Menyelesaikan Soal Cerita 
Program Linear Dengan Prosedur Newman. Jurnal Elektronik Pembelajaran Matematika, 5(2), 173185.

Santoso, D. A., Farid, A., \& Ulum, B. (2017). Error Analysis of Students Working about Word Problem of Linear Program with NEA Procedure. Journal of Physics: Conference Series, 855(1). https://doi.org/10.1088/1742-6596/855/1/012043

Satoto, S., Sutarto, H., \& Pujiastuti, E. (2012). Analisis Kesalahan Hasil Belajar Siswa Dalam Menyelesaikan Soal Dengan Prosedur Newman. Unnes Journal of Mathematics Education., 1(2). https://doi.org/10.15294/ujme.v1i2.1757

Savitri, D. A., \& Yuliani, A. (2020). Analisis Kesalahan Siswa Dalam Menyelesaikan Permasalahan Trigonometri Ditinjau Dari Gender Berdasarkan Newman. JPMI (Jurnal Pembelajaran Matematika Inovatif), 3(5), 463-474. https://doi.org/10.22460/jpmi.v3i5.463-474

Siswandi, E., Sujadi, I., \& Riyadi. (2016). Analisis kesalahan siswa dalam menyelesaikan masalah matematika kontekstual pada materi segiempat berdasarkan analisis Newman ditinjau dari perbedaan gender. Jurnal Elektronik Pembelajaran Matematika, 4(7), 633-643.

Sugiyono. (2017). Metode Penelitian Pendidikan Pendekatan Kuantitatif, Kualitatif, dan R\&D. Alfabeta.

Wiratomo, Y., \& Mulyatna, F. (2020). Use of Learning Management Systems in Learning Efforts during a Pandemic. Journal of Mathematical Pedagogy (JoMP), 1(2), 62-71.

Yazid, M., \& Ernawati, A. (2020). Hasil Belajar Siswa Di Mi Nw Pancor Kopong Pada Masa Pandemi Covid-19. Prima Magistra: Jurnal Ilmiah Kependidikan, 1(2), 205-209. https://doi.org/10.37478/jpm.v1i2.661 